\title{
Adolescent female tennis players: Injury prevalence and prevention
}

\author{
Harriet Rogers \& Lisa Taylor \\ School of Health Sciences, University of East Anglia.
}

\begin{abstract}
This literature review aimed to identify injury prevalence in adolescent female tennis players, and was conducted in accordance to the PRISMA guidelines (Shamseer et al., 2015). The lower extremity encountered the greatest number of injuries and musculotendinous injuries were the most common injury type. Injury prevalence and the anatomical location of injuries changed with chronological age. Acknowledging the results can help tailor strength and conditioning programmes to target the most prevalent injuries within each age group.
\end{abstract}

Key words: adolescent, female, injuries, tennis

Received: 18 January 2021

Acepted: 1 March 2021

Corresponding author: School of Health Sciences, University of East Anglia, Norwich Research Park, Norwich NR4 7TJ, UK. Email: Lisa. Taylor@uea.ac.uk

\section{INTRODUCTION}

Tennis is played by over 87 million people worldwide, making it one of the most popular global sports (ITF, 2019) with a growth in female participation. A literature review was undertaken to identify adolescent female specific injury prevalence and prevention, to help tailor coaching programmes accordingly. Many injury risk factors are unfortunately non-modifiable. It is important for coaches to be aware and take advantage of any risk factors that can be modified. The main injury prevention themes identified from the literature review are presented.

\section{METHODS}

The literature review used the Preferred Reporting Items for Systematic Reviews and Meta-Analysis (PRISMA) (Figure 1) (Shamseer et al., 2015). Inclusion criteria involved analysing female tennis players between 10-19 years, published in English between 2009-August 2019 and an evaluation of injury outcomes (incidence, prevalence, type, location, severity). A systematic search was performed utilising Medline Ovid as the primary electronic database and replicated in: Web of Science, Sport Discus, PsychInfo, Scopus and CINAHL, with predefined the keywords and Boolean terms displayed in Table 1.

\section{Table 1}

Search Strategy Keywords and Boolean Terms.

$$
\begin{gathered}
\text { Tennis } \\
\text { AND } \\
\text { Girl* OR Female* } \\
\text { AND } \\
\text { Adolescen* } \\
\text { AND }
\end{gathered}
$$

Athletic injur* OR Injur* OR Caus* OR Epidemiol* OR Etiolog* OR Aetiolog* OR Mechanism* OR Preval* OR Inciden* OR Occur* OR Propor* OR Distribut* OR Populat* OR Risk factor* OR Predispos* OR Acciden*

*Truncation: used to identify all possible endings of the key term; AND: searches for two terms and limits the search; OR: searches for two or more terms and widens the search

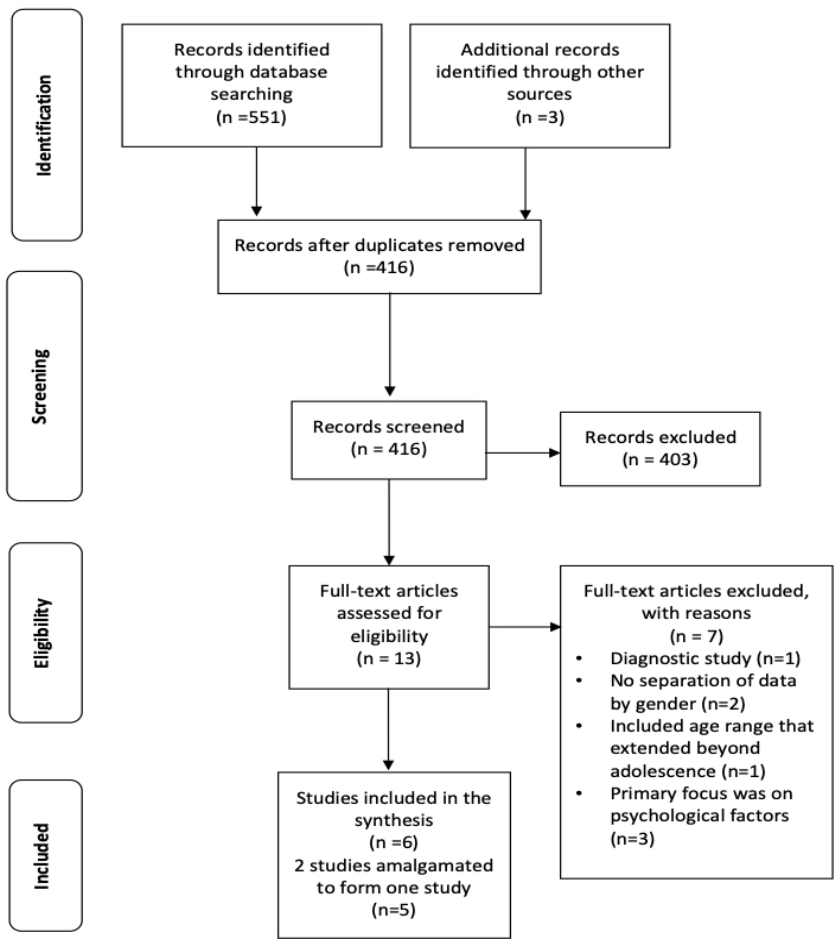

Figure 1. PRISMA flow chart of literature retrieval and selection. 


\section{DISCUSSION}

Table 2

Characteristics of the reviewed studies.

\begin{tabular}{|c|c|c|c|c|c|}
\hline Reference & Objective & Study Design & Study Population & $\begin{array}{l}\text { Age of Participants } \\
\text { (Years; Mean } \pm \text { SD) }\end{array}$ & Injury Rates \\
\hline $\begin{array}{l}\text { Correia et al., } \\
2016\end{array}$ & $\begin{array}{l}\text { Present a profile of medical } \\
\text { complaints in ITF junior and } \\
\text { Pro circuits tournaments }\end{array}$ & $\begin{array}{c}\text { Prospective } \\
\text { Cohort }\end{array}$ & $\begin{array}{c}\mathrm{N}=816 \\
\text { Male: } 474 \\
\text { Female: } 342\end{array}$ & $\begin{array}{c}\text { Male: } 16.28 \pm 0.56 \\
\text { Female: } 15.72 \pm 0.41 \\
\text { Total: } 16.06 \pm 0.47\end{array}$ & $\begin{array}{c}\text { Complaints }(95 \% \mathrm{Cl}) \text { : } \\
\text { Per match: } 0.43(0.29-0.56) \\
\text { Per } 1000 \text { games: } 23.00(15.72-30.28) \\
\text { Per } 1000 \text { hours: } 337.59(220.32-447.27)\end{array}$ \\
\hline $\begin{array}{l}\text { Gescheit et al., } \\
2012\end{array}$ & $\begin{array}{l}\text { To profile multi-year injury } \\
\text { incidence and severity trends } \\
\text { in elite Junior tennis players } \\
\text { from a national program }\end{array}$ & $\begin{array}{l}\text { Prospective } \\
\text { Cohort }\end{array}$ & $\begin{array}{c}\mathrm{N}=101 \\
\text { Male: } 58 \\
\text { Female: } 43\end{array}$ & $13-18$ & $\begin{array}{c}\text { Incidence per } 1000 \text { hours (mean } \pm S D \text { ): } 2.8 \\
\pm 0.0\end{array}$ \\
\hline $\begin{array}{l}\text { Jayanthi et al., } \\
2009\end{array}$ & $\begin{array}{l}\text { To Investigate the association } \\
\text { between medical withdrawals } \\
\text { and age, sex, match volume } \\
\text { and match type }\end{array}$ & $\begin{array}{c}\text { Retrospective } \\
\text { Cross-sectional } \\
\text { Cohort }\end{array}$ & $\begin{array}{c}\mathrm{N}=\mathbf{2 8 , 3 3 6} \\
\text { (exposures) } \\
\text { Male: } 14,108 \\
\text { Female: } 14,105 \\
\text { Unavailable: } 123\end{array}$ & $12-18$ & $\begin{array}{c}\text { Medical withdrawals per } 1000 \text { match } \\
\text { exposures: } 14.0\end{array}$ \\
\hline $\begin{array}{c}\text { Kovacs et al., } \\
2014\end{array}$ & $\begin{array}{l}\text { To analyse a series of } \\
\text { demographic, technique, } \\
\text { injury and training related } \\
\text { questions in competitive } \\
\text { Junior tennis players }\end{array}$ & $\begin{array}{l}\text { Prospective } \\
\text { Cohort }\end{array}$ & $\begin{array}{c}\mathrm{N}=832 \\
\text { Male: } 356 \\
\text { Female: } 476\end{array}$ & $10-17$ & l \\
\hline
\end{tabular}

\section{INJURY CLASSIFICATION, TYPE AND ANATOMICAL DISTRIBUTION}

Acute, traumatic injuries accounted for $34.5-44.4 \%$ and overuse injuries explained up to $55.6-65.5 \%$ of reported of female injuries. Overuse injuries were more frequent in the upper extremities $(75 \%)$ than the trunk $(67 \%)$ or lower extremity (39\%). Injury severity analysis reveal nearly $50 \%$ of female injuries were classified as severe and required $>28$ days to return to participation (Correia et al., 2016; Hjelm et al., 2012). Musculotendinous complaints were the most common injury representing $71.3 \%$ of all female injuries, followed by joint injuries (17.2\%). Ligaments were the most common injury within a joint, representing $12.1 \%$ of all injuries. The anatomical distribution of injuries revealed the lower extremity was the most prevalent injury site (41.4\%), followed by the upper limb (29.9\%) and the lower back/ trunk (22.2-25.90\%). When analysed more acutely by subregions the lower back/lumbar spine accounted for $12.1 \%$ of trunk injuries, the shoulder recorded the highest number of injuries in the upper limb (16.7\%) and the knee represented $14.9-18.5 \%$, of total lower limb injuries in female adolescent players (Correia et al., 2016; Hjelm et al., 2012). The results of anatomical injury location is presented in Table 3.

\section{AGE}

Of particular interest to coaches is the reported increase in injury prevalence with chronological age (13-18 years) from $2.0 \pm 0.2$ to $2.9 \pm 0.1$ injuries per 1000 exposure hours
(Gescheit et al., 2019). In adolescents 14 years and under the shoulder was the most dominant injury location, followed by the hip/groin (Gescheit et al., 2019; Kovacs et al., 2014). The knee was particularly prevalent in the under-16 category (Kovacs et al., 2014). However, a consistent observation between 14-18 years of age was the high prevalence lumbar spine injuries (Gescheit et al., 2019).

\section{THE SHOULDER}

A considerable proportion of injuries occur in a player's dominant shoulder (Fernandez-Fernandez et al., 2019) and are overuse in nature (Ellenbecker et al., 2009). The high level of repetition involved in tennis places the shoulder and particularly the rotator cuff at risk of sport specific muscular adaptations (i.e., a muscular imbalance and a loss of internal rotation ROM) (Fernandez-Fernandez et al., 2019). The research suggests that from an early age players are developing a high incidence of shoulder related injuries. Therefore, should be a prevention focus as early as possible in players.

\section{LUMBAR SPINE}

The spine is at considerable risk of injury, particularly if the correct technique is not executed (Salzmann et al., 2018). The serve is frequently associated with the development of lower back pain in adolescent players, due to the high-level of muscular activation and mechanical loading. The kick serve, commonly introduced between $12-15$ years of age (Campbell 
Table 3

Injury Anatomical Distribution.

\begin{tabular}{|c|c|c|c|c|c|}
\hline & Correia et al., 2016 & Hjelm et al., 201C & ; Hjelm et al., 2012 & Gescheit et al., 2019 & Kovacs et al., 2014 \\
\hline & $\begin{array}{c}\text { Number of } \\
\text { complaints/Total } \\
\text { complaints (\%) }\end{array}$ & $\begin{array}{c}\text { Incidence per } \\
1000 \text { hours (95\% } \\
\text { Cl) }\end{array}$ & $\begin{array}{l}\text { Incidence per } 1000 \\
\text { hours (Mean } \pm \text { SD) }\end{array}$ & $\begin{array}{l}\text { Percentage of } \\
\text { Injuries (\%) }\end{array}$ & $\begin{array}{l}\text { Incidence per } 1000 \\
\text { hours (Mean } \pm \text { SD) }\end{array}$ \\
\hline Foot & 6/174 (3.4) & & $1.9 \pm 0.4$ & $2-8$ & $1.9 \pm 0.4$ \\
\hline Ankle & $9 / 174(5.2)$ & & $2.3 \pm 0.3$ & $9-17$ & $2.3 \pm 0.3$ \\
\hline Knee & 26/174 (14.9) & & $2.0 \pm 0.2$ & $8-22$ & $2.0 \pm 0.2$ \\
\hline Thigh & 26/174 (14.9) & & $1.6 \pm 0.1$ & $2-5$ & $1.6 \pm 0.1$ \\
\hline Hip/Groin & 0 & & $1.4 \pm 0.2$ & $0-5$ & $1.4 \pm 0.2$ \\
\hline Lower back & 21/174 (12.1) & & $3.9 \pm 0.2$ & $4-17$ & $3.9 \pm 0.2$ \\
\hline Shoulder & 29/174 (16.7) & & $2.6 \pm 0.2$ & $11-25$ & $2.6 \pm 0.2$ \\
\hline Elbow & $8 / 174(4.6)$ & & $1.7 \pm 0.3$ & $3-4$ & $1.7 \pm 0.3$ \\
\hline Wrist and Hand & $8 / 174(4.6)$ & & $2.4 \pm 0.2$ & $9-10$ & $2.4 \pm 0.2$ \\
\hline Head/Neck & $5 / 174(2.9)$ & & $0.5 \pm 0.1$ & $0-1$ & $0.5 \pm 0.1$ \\
\hline Other & 0 & & 0 & $10-17$ & 0 \\
\hline Upper extremity & 52/174 (29.9) & $0.1(0.03-0.25)$ & $6 / 27(22.2)$ & & \\
\hline Lower extremity & $73 / 174$ (41.4) & $0.3(0.16-0.50)$ & $14 / 27$ (51.9) & & \\
\hline Lower back/Trunk & $45 / 174(25.9)$ & $0.2(0.04-0.29)$ & $7 / 27$ (25.6) & & \\
\hline
\end{tabular}

et al., 2013), potentially contributes to the high incidence of lumbar spine injuries. A commonly observed predisposing factor is muscular imbalance. Injury prevention should focus on extensive core stability, involving both flexor and extensor muscular development. Rotational exercises are required to build resilience to the high repetitive demands (Ellenbecker et al., 2009).

\section{HIP AND GROIN}

The loading, multidirectional movements and extreme range of motion that are demanded of the hip during tennis, place the joint and the surrounding soft tissue structures at risk of injury (Safran, 2014). The hip joint muscles play a vital role in the transfer of forces through the kinetic chain. Hip muscle strength can impact the load through the joint, altering its function, impacting injury risk, not only to the hip but also the lower back and knee (Ellenbecker et al., 2009).

\section{KNEE}

A high prevalence of knee injuries was observed particularly in females of 16 years of age. Many knee injuries share similar risk factors that can be targeted. Both ligaments injuries and patellofemoral pain are often associated with muscle weakness, and /or imbalance and limited flexibility in the knee and pelvic-femoral region. A decreased level of neuromuscular control around the knee has been reported in female athletes during maturational growth (Hewett et al., 2004), potentially contributing to the increased level of knee injuries witnessed.

Integrating core stability training into an athletes training has been demonstrated to be crucial in preventing and reducing injuries, particularly to the lower limb. It has been suggested that the core is the foundation of the kinetic chain and facilitates the transfer of energy from the lower to the upper extremities (Huxel-Bliven \& Anderson, 2013) which is pivotal in tennis and for enhancing performance. The exercises below focus on some core exercises that provide stability for the tennis player (Huxel-Bliven \& Anderson, 2013). The subsequent region specific exercises, focus on the most prevalent female adolescent injuries identified from the literature review. These exercises may be useful to incorporate into an adolescent female's injury prevention strength and conditioning routine.

Core stabilisation exercise:

\section{Bridge:}

- Trains the back, abdominal and gluteal muscles simultaneously

- Lie on your back with knees flexed to $90^{\circ}$

- Push pelvis up

- Ensure the pelvis and torso are in one line

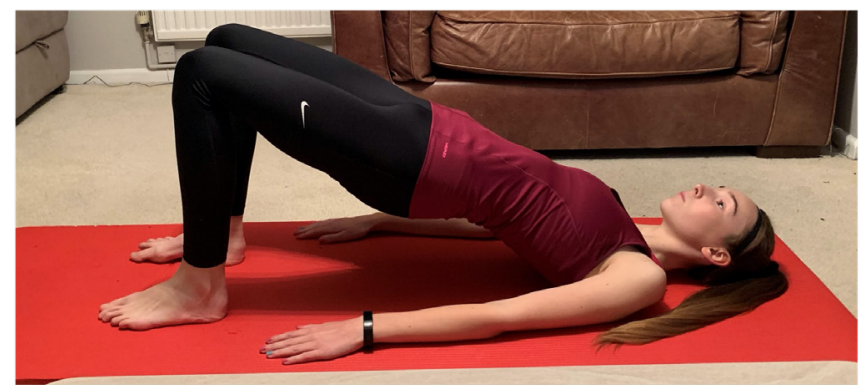

Figure 2. Brige. 


\section{Dead bugs:}

- On your back place hips and knee at $90^{\circ}$

- Lower opposite arm and leg

- Keep the small of your back pushed into the ground by activating your core and do not compensate by arching the back

- Develops lumbopelvic stability

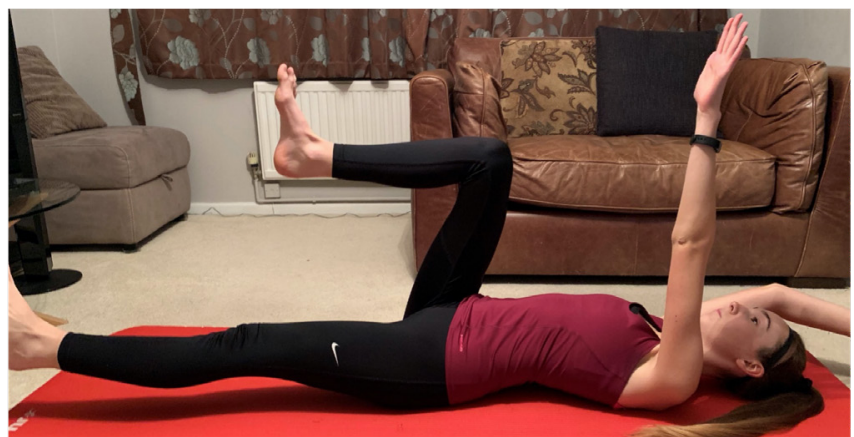

Figure 3. Dead bugs.

\section{Superman exercise:}

- In four point kneeling with a neutral spine

- Extend opposite arm and leg

- Engage core muscles and do not hyperextend their spine when extending the leg

- Targets the gluteal, hamstrings, external obliques and back muscles

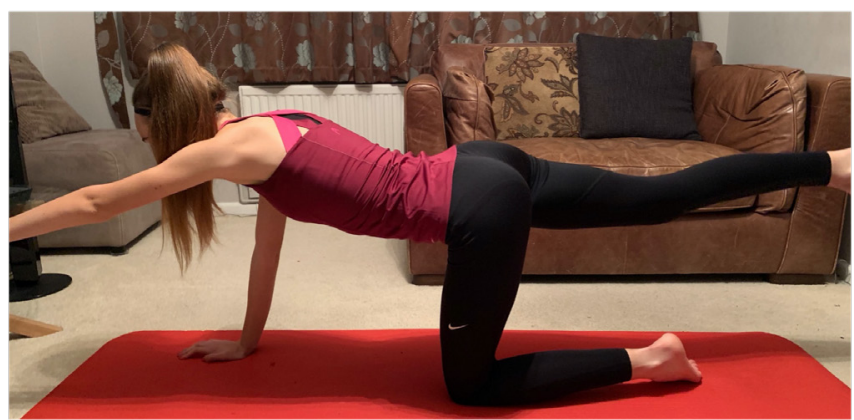

Figure 4. Superman exercise.

\section{Side Plank:}

- Lying on side

- Lift up into a side plank with feet stacked or one foot in front of the other

- Ensure a straight line from feet to shoulders

- This targets the Abdominal muscles (external obliques, rectus abdominus), back muscles and gluteus medius

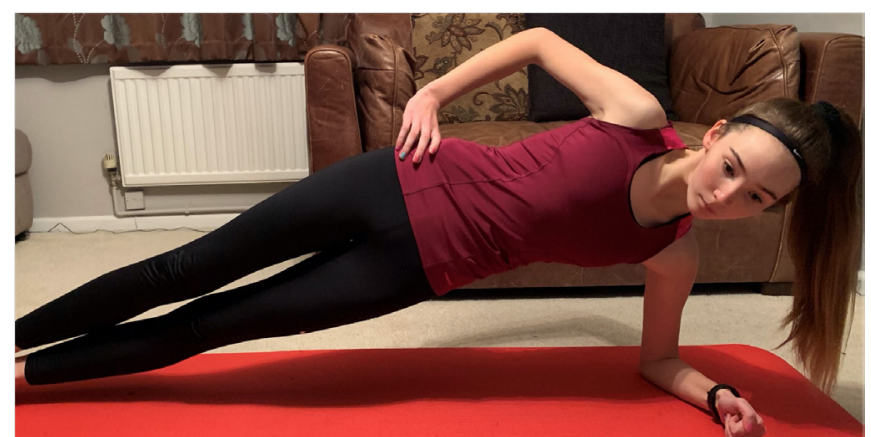

Figure 5. Side Plank.

Many exercises focus on one particular region but can be beneficial for other anatomical locations due to the pivotal role of the whole kinetic chain in tennis. Below are some region specific exercises.

\section{Shoulder Emphasis:}

- Lawnmower exercises: initiating the exercise with the lower extremities increases scapular muscle activation and recruitment (Funk et al., 2018)

- The step-up with resistance band: requires hip extension and this reinforces gluteal and sequential activation throughout the kinetic chain. The resistance band also reinforces rotator cuff muscle activation (Funk et al., 2018).

- Shoulder external rotation with resistance band: providing support to the working limb will also ensure selective recruitment of the rotator cuff muscles (Funk et al., 2018)

\section{Lower extremity}

- Clams and Reverse Clams: to target hip Internal and external rotation, perform on both sides to work on achieving symmetrical hip rotational strength in the lower limbs (Ellenbecker \& Pluim, 2009).

- Multidirectional lunge: To strengthen hip, knee, ankle and core stability while also challenging dynamic balance, required for multidirectional movements in tennis (Samson et al., 2007; Huxel-Bliven \& Anderson, 2013)

- Single leg squat: Focuses on improving neuromuscular control particularly of the knee (Hewett et al., 2004), targets the gluteal muscles, while also challenging core stability. Poor gluteal strength has also been linked with reduced shoulder performance in overhead sports (Funk et al., 2018).

\section{CONCLUSION}

Adolescent female players need to be provided with core strength and conditioning and also more specific strength and conditioning that is tailored to prevent the most prevalent age related injuries that have been reported in the literature. Further research focusing on adolescent female injury is recommended, as the current paucity of research impacts on evidence based targeted injury prevention programmes for this group of tennis players. 


\section{REFERENCES}

Campbell, A., Straker, L., O'Sullivan, P., Elliott, B. \& Reid, M. (2013) Lumbar loading in the elite adolescent tennis serve: link to low back pain. Medicine and Science in Sports and Exercise, 45(8), 1562-8. https://doi.org/10.1249/MSS.0b013e31828bea5e

Correia, J. P. (2016) Injury surveillance at 23 International Tennis Federation junior and procircuit tournaments between 2011 and 2015 [Supplementary material (unpublished)]. British Journal of Sports Medicine, 1-11. Available at: https://bjsm.bmj.com/content/50/24/1556\#supplementary-materials (Accessed: 30 July 2019) https://doi.org/10.1136/bjsports-2016-096255

Ellenbecker, T., Pluim, B., Vivier, S. \& Sniteman, C. (2009). Common injuries in tennis players: exercises to address muscular imbalances and reduce injury risk. National Strength and Conditioning Association, 31(4), pp. 50-58. https://doi.org/10.1519/SSC.0b013e3181af71cb

Fernandez-Fernandez, J., Nakamura, F. Y., Moreno-Perez, V., LopezValenciano, A., Del Coso, J., Gallo-Salazar, C., Barbado, D., Ruiz-Perez, I. \& Sanz-Rivas, D. (2019). Age and sex-related upper body performance differences in competitive young tennis players. PLOS ONE, 14(9), 1-18. https://doi.org/10.1371/journal.pone.0221761

Funk, L., Leftley, C., Gibson, J., Holmes, C. Richardson, E. (2018) Shoulder Rehabilitation: A Comprehensive Guide To Shoulder Exercise Therapy (2nd edn.). Shoulderdoc.co.uk

Gescheit, D. T., Cormack, S. J., Duffield, R., Kovalchik, S., Wood, T. O., Omizzolo, M. \& Reid, M. (2019). A multi-year injury epidemiology analysis of an elite national junior tennis program. Journal of Science and Medicine in Sport, 22(1), 11-15. https://doi.org/10.1016/j.jsams.2018.06.006

Hewett, T. E., Myer, G. D. \& Ford, K. R. (2004). Decrease in neuromuscular control about the knee with maturation in female athletes. Journal of Bone and Joint Surgery, 86(8), 1601-1608. https://doi.org/10.2106/00004623-200408000-00001
Hjelm, N., Werner, S. \& Renstrom, P. (2012). Injury risk factors in junior tennis players: a prospective 2-year study. Scandinavian Journal of Medicine and Science In Sports, 22(1), 40-48. https://doi.org/10.1111/j.1600-0838.2010.01129.x

Huxel-Bliven, K. \& Anderson, B. E. (2013) Core Stability Training for Injury Prevention. Sports Health, 5(6), 514-522. https://doi.org/10.1177/1941738113481200

International Tennis Federation (ITF) (2019). Key Findings. ITF Global Tennis Report. http://itf.uberflip.com/i/1169625-itf-global-tennis-report-2019overview/39?

Kovacs, M. S., Ellenbecker, T. S., Kibler, B. W., Roetert, P. E. \& Lubbers, P. (2014). Injury trends in American competitive junior tennis players. Journal of Medicine and Science in Tennis, 19(1), 19-23.

Safran, M. (2014). Evaluation of the painful hip in tennis players. Aspetar Sports Medicine Journal, 3, 516-525

Salzmann, S. N., Maquirriain, J., Shue, J. \& Girardi, F. P. (2018). Spine Injuries in Tennis. In: Di Giacomo, G., Ellenbecker, T. \& Kibler, W. (Eds.) Tennis Medicine (pp. 111-118). Springer. https://doi.org/10.1007/978-3-319-71498-1_8

Samson, K. A., Sandrey, M.A. \& Hetrick, A. (2007). A core stabilization program for tennis athletes, Athletic Therapy Today, 12 (3), 41-46. https://doi.org/10.1123/att.12.3.41

Shamseer, L., Moher, D., Clarke, M., Ghersi, D., Liberati, A., Petticrew, M., Shekelle, P. \& Stewart, L. (2015). PRISMA-P Group. Preferred reporting items for systematic review and meta-analysis protocols (PRISMA-P): elaboration and explanation. British Medical Journal, 2(349),1-25. https://doi.org/10.1136/bmj.g7647

Copyright (C) 2021 Harriet Rogers \& Lisa Taylor

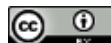

This text is under a Creative Commons BY 4.0 license

You are free to Share - copy and redistribute the material in any medium or format - and Adapt the content - remix transform, and build upon the material for any purpose, even commercially under the following terms:

Attribution: You must give appropriate credit, provide a link to the license, and indicate if changes were made. You may do so in any reasonable manner, but not in any way that suggests the licensor endorses you or your use. 